or less definite way. This change by itself modifies the phenotypic expression of the variable mutant 'Antennaless'. The quantity of yeast available per unit larval mass also changes in these cultures (see graph above). These two major variables will almost certainly affect the exhibition of polygenes. But these environmental changes do not follow the same course in all circumstances ${ }^{4}$. In particular, they are influenced very significantly by the changing numbers of larvæ present in the food medium (see accompanying graph). Hence, in selection experiments care must be taken to ensure that the fertility of females is not altered as selection proceeds. Indeed, Mather's surprising results ${ }^{1}$ may be explained by such a selection for fertility taking place at the same time as selection for the character studied.

As a corollary to this we may say that the study of polygenic inheritance will be successful only when the technical difficulties outlined above are overcome. As a contribution to their solution we suggest that experiments on selection and inheritance of polygenes in Drosophila be conducted using sterile culture media Such media reduce variability to a considerable degree and permit the handling of constant members of larvæ ${ }^{4}$.

C. GORDON.

Department of Natural History, J. H. SANG.

Marischal College,

Aberdeen.

May 5.

${ }^{1}$ Mather, K., $J$. Genet., 41, 159 (1941)

'Mather, K., NATURE, 149, 427 (1942).

"Hogben, L., "Nature and Nurture" (London, 1933).

- Gordon, C., and Sang, J. H., Proc. Roy. Soc., B, 130, 151 (1941).

\section{Absorption of Minimal Doses of $\beta$-Caro- tene by Vitamin A-Deficient Rats}

WIDE differences between the theoretically expected and experimentally obtained potencies of pure vitamin A as compared with $\beta$-carotene have led to a considerable amount of speculation ${ }^{1,2}$ on the possible manner of conversion of carotene into vitamin A in vivo. While there is no direct evidence in support of the postulated unsymmetrical fission of the provitamins, we felt that it might be of interest to study the extent of absorption of $\beta$-carotene by rats under the conditions of biological assay.

In the course of these experiments, it was observed that analysis of the fæces of rats maintained on a carotenoid-free diet gives an apparent carotene excre-

\begin{tabular}{|c|c|c|c|c|c|c|c|}
\hline \multirow[b]{2}{*}{$\begin{array}{l}\text { Coconui } \\
\text { jil con: } \\
\text { tent of } \\
\text { diet } \\
\text { (per } \\
\text { cent) }\end{array}$} & \multirow{2}{*}{$\begin{array}{l}\text { Level } \\
\text { of } \\
\text { dosage } \\
\mu \text { ym. } \\
\beta \text { caro- } \\
\text { ene pes } \\
\text { rat per } \\
\text { day }\end{array}$} & \multirow[b]{2}{*}{$\begin{array}{l}\text { Imoun } \\
\text { of } \\
\beta \text {-caro* } \\
\text { tene } \\
\text { ingestec } \\
\text { ( } \mu \text { gm. })\end{array}$} & \multirow[b]{2}{*}{ 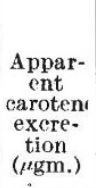 } & \multicolumn{3}{|c|}{ On separation } & \multirow[b]{2}{*}{$\begin{array}{c}\beta \text {-caro- } \\
\text { tene } \\
\text { excre- } \\
\text { tion } \\
\text { (per } \\
\text { ecnt) }\end{array}$} \\
\hline & & & & $\begin{array}{c}\text { Non- } \\
\text { caro- } \\
\text { tene } \\
(\mu \mathrm{gm} . \\
\text { equiv. })\end{array}$ & $\begin{array}{c}\beta \text {-caro- } \\
\text { tene } \\
\text { found } \\
(\mu \mathrm{gm} .)\end{array}$ & $\begin{array}{c}\beta \text {-caro- } \\
\text { tene } \\
\text { calcu- } \\
\text { lated } \\
(\mu \mathrm{gm} .)^{*}\end{array}$ & \\
\hline 3 & 1 & $224 \cdot 5$ & $114 \cdot 9$ & $27 \cdot 3$ & $28 \cdot 7$ & $31 \cdot 9$ & $14 \cdot 0$ \\
\hline , & 2 & $448 \cdot 9$ & $159 \cdot 0$ & $40 \cdot 4$ & $49 \cdot 8$ & $55 \cdot 3$ & $12 \cdot 3$ \\
\hline 10 & 1 & $204 \cdot 0$ & $117 \cdot 0$ & $36 \cdot 0$ & $22 \cdot 8$ & $25 \cdot 3$ & $12 \cdot 6$ \\
\hline , & 2 & $544 \cdot 0$ & $190 \cdot 5$ & $59 \cdot 4$ & $59 \cdot 5$ & $66 \cdot 1$ & $12 \cdot 0$ \\
\hline
\end{tabular}

- Chromatographic analysis of known mixtures has shown the carotene recovery to be about 90 per cent, and these values are calculated on this basis. tion value of $0 \cdot 2-0 \cdot 4 \mu \mathrm{gm}$. per rat per day. Examination in a visual spectrophotometer showed this to be due to a non-carotene pigment possessing only a general absorption. By chromatographic adsorption analysis on columns of Brockman's alumina it was possible to separate the carotene from the associated impurity and estimate it quantitatively. The identity of the excreted carotene and the non-carotene nature of the other pigment were confirmed by spectrophotometric data and growth experiments on rats.

Some experimental results are summarized in the accompanying table.

The figures presented in this table represent the total amounts for each group of 6-7 rats over an experimental period of 5-6 weeks.

It should be mentioned, however, that in order to get sufficient quantities of the pigments, it was necessary to collect the fæces of each group of rats for 10-14 days and preserve the same in the refrigerator before analysis could be performed. During this interval, a part of the carotene might have undergone destruction and therefore it is probable that the actual excretions were considerably higher than these figures would indicate.

In contrast to the behaviour of carotene, which may be due to its hydrocarbon nature, vitamin $A$ is known to be quantitatively absorbed at far higher levels of intake; at any rate, no excretion could be detected $^{3,4}$. It is therefore suggested that the incomplete absorption of $\beta$-carotene might be the major factor responsible for the observed discrepancies; after absorption, perhaps $\beta$-carotene is as efficient as vitamin $A$ at the levels of the biological assay.

In a note ${ }^{5}$ which reached us during the final stages of this investigation, Wald et al. arrive at a similar conclusion based on the results of absorption studies on human subjects at higher levels of intake.

Further work is in progress and full details will be published elsewhere.

\section{G. B. Ramasarma.}

D. N. Hakim.

Department of Biochemistry,

Indian Institute of Science, Bangalore. March 19.

${ }^{1}$ Underhill, S. W. F., and Coward, K. H., Biochem. J., 33, 594 (1939). ${ }^{2}$ Morton, R. A., Chem, and Ind., 59, 307 (1940).

"Wilson, H. E. C., Das Gupta, S. M., and'Ahmad, B., Indian J. Med. Research, 24, 807 (1937).

'De, N. K., Ind. J. Med. Research, 24, 751 (1937).

s Wald, G., Carrol, W. R., and Sciarra, D., Science, 94, 95 (1941).

\section{Chemical Composition of Mitochondria}

IN 1908 Regaud $^{1}$ suggested that mitochondria were "corps lipoiddes", and the following year" he pointed out the general resemblance between the myelin of nerve fibres and the substance of mitochondria in their reactions to histological fixation and staining. The theory that mitochondria contain a relatively large amount of lipines held its ground for a quarter of a century.

In 1934 Bensley and Hoerr ${ }^{3}$ succeeded in actually separating the mitochondria of the liver of the cavy from the rest of the cell, and produced cakes of nearly pure mitochondrial substance in considerable quantity. Roughly a third of this substance is soluble in fatsolvents 4 , and it was naturally anticipated that a large proportion of this would consist of lipines. On the addition of acetone, however, a very small precipitate 